\title{
REAPPROPRIATING THE BALKAN ROUTE: MOBILITY STRUGGLES AND JOINT-AGENCY IN BOSNIA AND HERZEGOVINA
}

\author{
Andrej KURNIK!, Maple RAZSA"
}

COBISS 1.01

\section{ABSTRACT \\ Reappropriating the Balkan Route: \\ Mobility Struggles and Joint-Agency in Bosnia and Herzegovina}

In this article the authors question how the EU's enlistment of the post-Yugoslav states into the EU's border regime has exacerbated local nationalisms. They also question how, on the other hand, migrant struggles to cross this territory have intersected with local movements against nationalism and silenced political alternatives. They use the notion of joint-agency, that is, the co-articulation of mobility struggles and antinationalist struggles, in ex-Yugoslavia to read the recent history of the route across the region generally and the current predicament in Bosnia and Herzegovina in particular. This alternative reading facilitates an understanding of the potential of struggles for freedom of movement to reanimate a critique of the coloniality of power in the EUropean borderlands such as the Balkans.

KEYWORDS: migration, social movements, autonomy, Bosnia and Herzegovina, Balkans, Europe

\section{IZVLEČEK}

\section{Reapropriacija Balkanske poti:}

\section{Boji za mobilnost in so-delujočnost v Bosni in Hercegovini}

Avtorja se v članku sprašujeta, kako je vloga postjugoslovanskih držav v restavraciji mejnega režima Evropske unije zaostrila nacionalizme in kakšen je bil po drugi strani spoj med migrantskimi boji, lokalnimi antinacionalističnimi gibanji in zamolčanimi političnimi alternativami? Pojem so-delujočnost bojev za mobilnost in antinacionalističnih bojev na območju nekdanje Jugoslavije omogoča branje nedavne zgodovine migrantske poti skozi regijo in ožje razumevanje trenutnih tegob zaradi t. i. migrantske krize v Bosni in Hercegovini. Takšno alternativno branje omogoča razumeti potencial, ki ga imajo boji za svobodo gibanja za oživitev kritike kolonialnosti oblasti na mejnem območju EU, kakršno je Balkan.

KLJUČNE BESEDE: migracija, družbena gibanja, avtonomija, Bosna in Hercegovina, Balkan, Evropa

$\mathrm{PhD}$ in Political Science, Assistant Professor; University of Ljubljana, Faculty of Social Sciences, Kardeljeva ploščad 5, SI-1000 Ljubljana; andrej.kurnik@fdv.uni-lj.si

॥ PhD in Anthropology, Associate Professor, Global Studies Program; Colby College, Waterville, ME 04901-8841; mjrazsa@colby.edu 


\section{INTRODUCTION}

In recent years, we have conducted militant research with diverse people on the move ${ }^{1}$-that is, studying and contributing to mobility struggles - before, during, and after the dramatic 2015-2016 "long summer of migration" (Kasparek, Speer 2015). This research has involved investigating a series of border struggles across the territory of ex-Yugoslavia - a region pivotal to nearly all the many permutations of the "Balkan Route" (Lunaček Brumen, Meh 2015; Kurnik 2015; Beznec, Speer, Stojić Mitrović 2016; Hameršak, Pleše 2017; Ahmetašević, Mlinarević 2019). Here, we draw on our participation in various activist initiatives, such as Info Kolpa (2019), ${ }^{2}$ in Bosnia and Herzegovina $(\mathrm{BiH})$ - site of the most urgent contemporary mobility struggles in the Balkans. A series of questions emerge from this experience. What are the consequences of the EU enlisting $\mathrm{BiH}$ and the wider ex-Yugoslav region into the EU border regime? Does this EUropeanization - the expansion of the European Union and the extension of its influence into hopeful future members - push "The Balkans" toward resolving ethnic conflicts and encouraging tolerance, as is so often claimed? Or, do struggles around the route - and their implication in other dimensions of longer-standing processes of Europeanization, ${ }^{3}$ including geopolitical, racial, and colonial hierarchies - indicate that the processes of EU integration and Yugoslav disintegration are mutually reinforcing rather than opposing? At the same time, do mobility struggles bring to the surface and reanimate submerged local histories of antinationalism, refugeehood, anticolonialism, and heterogeneity?

In what follows, we first situate contemporary struggles of people on the move in $\mathrm{BiH}$ within the larger history of the route, especially as it developed across exYugoslavia. Narrating how the route was opened makes clear - in contrast to the many state-centric accounts of the Balkan Route - the role of migrant agency, expressed in the carving of unruly itineraries across the Balkans and temporarily suspending the EUropean migration regime (De Genova 2017). Attention to border struggles at particular localities allows us to generate concepts crucial to making sense of contemporary $\mathrm{BiH}$. We draw on the autonomy of migration literature - which rejects state-centered analyses that understand border and migration regimes as dictated by the sovereign power of the nation-state - stressing the primacy of mobility struggles (Casas Cortes, Cobarrubias, Pickles 2015) instead. We extend that theorization by attending to how migratory "escape paths" are not enacted across empty

1 We generally use "people on the move", or "people", eschewing the classifications through which authorities "divide and partition" migrant multiplicities and manage mobility (Tazzioli 2017).

2 Info Kolpa is a collective from Ljubljana that is involved in various solidarity initiatives with people on the move. One of the main activities of the collective has been to monitor the situation on the border between Slovenia and Croatia and to inform the broader public about the plight of people on the move.

3 Throughout the text, we will use the terms EUropeanization and EUropean to designate processes related to the expansion of the EU, and the terms Europeanization and European to designate longer-standing processes. 
space but necessarily intersect with local struggles against state sovereignty and, in ex-Yugoslavia, with resistance to a palimpsest of Europeanization processes. This conjuncture of mobility struggles and local struggles, experiences, and traditions we term joint-agency.

Second, we attend to how states, confronted with a thoroughly disrupted border regime, turned to processes of formalization, which - though these processes initially accelerated mobility along the route - were also crucial in the repression of mobility. We conclude this history with the increasing criminalization of solidarity and state reliance on illegal pushbacks of migrants seeking asylum. These state practices led people on the move to redirect the route into $\mathrm{BiH}$ and precipitated the current predicament in $\mathrm{BiH}$. Using a critical reading of Europeanization - including its articulation with Islamophobia, racialization, and the enforcement of the nation-form (Balibar 2004) on this diverse territory - we describe how layered processes of Europeanization have been pivotal to controlling mobility in $\mathrm{BiH}$. What is more, Europeanization not only attacks joint-agency, it also corrodes inclusive forms of local self-government and imposes exclusive subordinate forms of government. In conclusion, we consider how, from the vantage point of joint-agency, a new narrative of the Balkan Route (and migrant routes in general) can contribute to amplifying local critiques of Europeanization as an imposition of (neo)colonial domination and to valorizing the reanimation of the popular local conceptualization of common life based on diversity and heterogeneity.

\section{THE HISTORY OF THE SO-CALLED BALKAN ROUTE}

\section{Opening the Route}

In many accounts, Angela Merkel opened the Balkan Route with her declaration of an open-door policy and the suspension of the Dublin Regulation in September 2015. She only made this decision, however, when thousands of people on the move, frustrated with their mistreatment in Hungary, took over the highway from Budapest and walked toward Austria and Germany in a "March of Hope" (Kasparek, Speer 2015). Merkel's response, in other words, was less a gift than a concession to successful mobility (El-Shaarawi, Razsa 2019). Nevertheless, the perception lingers that state policies determined the course of this "crisis". Furthermore, core European states are often viewed as having responded to the Balkan Route in a more permissive, welcoming, and tolerant manner than Eastern and Southeastern European states, epitomized by images of Hungarian police teargassing and beating migrants at their border.

The September 2015 March of Hope, animated by people on the move, was the culmination of a series of migrant struggles across that "long summer of migration", struggles which saw state authorities repeatedly make previously unimaginable 
concessions to mobility. To be sure, for years, people had made their way to Europe, often clandestinely with the help of smugglers, along the so-called Balkan Route, as it was initially designated by Frontex (alluding to the region's reputation for criminality, especially smuggling). We reappropriate this name here, both as a recognition that these collective struggles deserve a proper noun and to affirm rather than denigrate the Balkan character of the route. In any case, the route grew dramatically for a variety of reasons during the spring and summer of 2015 (including deteriorating conditions in Syria and surrounding states that hosted refugees). The swelling numbers of people along the route changed the character of mobility: people were suddenly able to travel without smugglers and, when stopped by police, to mount collective actions against immobilization, including across the territory of ex-Yugoslavia (El-Shaarawi, Razsa 2019). The struggles at the borders of Macedonia, Serbia, Croatia, and Slovenia, from which we offer a few examples here, therefore built upon earlier struggles that stretched back across Greece, the Eastern Aegean, Turkey, and deep into the Middle East, Central Asia, and Sub-Saharan Africa.

We begin with examples in the south and work our way northward (as each struggle enabled the presence of people on the move at the next border struggle). In Preševo, a majority Albanian municipality stretching along the Serbian side of the Serbian-Macedonian border, our research on solidarity initiatives led us to local youth activists who intervened in July 2015 when local merchants, hoteliers, and taxi-drivers charged migrants exploitative prices. Mobilizing the local community's own experience of fleeing the violence of the Serbian military in 1999, they appealed to their neighbors, saying, "How can we mistreat these people, when we fled across the same fields they are traveling when we were refugees?" Where these appeals were not successful, they distributed thousands of fliers informing people on the move what prices they could expect to pay for services in Preševo.

Furthermore, these youth activists introduced us to a local imam who housed refugees in empty homes and apartments, a practice made possible by the labor migration of most of the residents of his village to Switzerland. It turned out that the imam, who had studied theology in Syria through the Non-Aligned Movement, had initially hosted small groups in his mosque but then expanded his assistance when thousands began arriving per day. The imam and youth activists alike situated their activities in longstanding Albanian traditions of autonomous and nonviolent organizing associated with Ibrahim Rugova - organizing which emerged to resist Serbian apartheid-like repression of ethnic Albanians in the 1980s - and which was largely extinguished by the rise of the Kosovo Liberation Army and the Western intervention of 1998-1999. Crucially, Preševo was in Serbia proper, not in Kosovo, so autonomy was not conflated with state sovereignty and took on decidedly non-sovereigntist and minoritarian hues (lbid.).

After the March of Hope, Hungary completed the wall along its southern border with Serbia on 15 September 2015. People on the move began seeking itineraries westward toward Croatia. Like in Preševo, the Croatian-Serbian border ran alongside 
sites of ethnonationalist violence, some of the worst of the 1991-1995 war. That conflict tore across the ethnically-mixed area of Croatia's Eastern Slavonia, first at the expense of Croats, then through the ethnic cleansing of Serbs, as both ethnonationalist projects attempted to create "pure" territory. Here too, many local residents explained their welcoming attitudes toward, and solidarity initiatives with, migrants in terms of their own experiences of refugeehood. The response of local people was especially strong when the route was informal and the state had not yet taken control through formalization, discussed below.

What is more, numerous Croatian organizations and informal initiatives pressed, and continue to press, for welcoming state policies, setting the tone for Croatia's initially warm public response to people on the move. They include, most prominently, Are you Syrious? and the Welcome Initiative co-initiated by the Centre for Peace Studies (CMS), which adopted a strategy of "mainstreaming solidarity" and welcoming rhetoric in Croatia (Beznec 2019). Many of the individual activists and organizations involved emerge from a series of antinationalist and transnational solidarity initiatives in recent Croatian history, with CMS, for example, emerging from the Antiwar Campaign of Croatia, which resisted the rise of belligerent nationalism and war in Croatia.

Only a few days after people on the move opened the route into Croatia, they headed toward Slovenia in the northwest, where the Slovenian authorities attempted to close the border (Kurnik 2015). A network of Slovenian activists, many with past experiences in migrant struggles, including struggles against the "Erasure", Slovenia's bureaucratic analog to the ethnic cleansing seen in Croatia and BiH (Razsa, Kurnik 2012), arrived to show support for the route. After 36 hours in the rain, the crowds trapped in the no-man's land between Croatia and Slovenia at the major border crossing of Bregana-Obrežje were losing patience with the Slovenian authorities' refusal to allow them to pass. Refugees and activists took coordinated action, largely at the initiative of the Iranians and Afghans present, and blockaded the entire highway. Soon the lines of immobilized trucks, busses, and cars stretched for dozens of kilometers to the south, and the authorities relented, providing free commercial busses to convey people onward to Austria (Kurnik 2016; El-Shaarawi, Razsa 2019).

To be clear, the opening of the Balkan Route was, undoubtedly, driven first and foremost by migrant mobility, by the incorrigible insistence of people on the move that they would find a way to continue on their way regardless of state reaction. Attention to the border struggles along the route makes the shifting-yet-assertive quality of this power plain. So, in this sense, the route certainly confirms the theorizing of the autonomy of migration, if in perhaps particularly dramatic conditions, in which the line between migration and more recognizable social movement activity is particularly thin and porous. However, this migration was neither crossing empty space nor only crossing national territory and its always unequally distributed forms of state enforcement. The Balkan Route articulated with a series of local struggles, many of which, in the case of the territory of ex-Yugoslavia, can be traced 
to traditions of resistance ${ }^{4}$ to the violent imposition of the nation-state form - itself a crucial dimension of Europeanization. We argue that this co-articulation of struggles against state sovereignty, ${ }^{5}$ or the crossing of what Papadopoulus et al. (2008) call "paths of escape from state sovereignty" has been a persistent characteristic of the Balkan Route (and is likely replicated in other settings), and can be understood as a form of joint-agency.

\section{From Formalization to Criminalization}

It is important to remember that, with the notable exception of Hungarian state policies, states along the route did not respond initially with violent repression. There was, rather, a relatively long period of formalization that effectively accelerated the number of travelers while also enabling eventual closure far from the European core. Slovenian authorities, for example, feared that border disorder might lead Austria and Italy to introduce border controls and effectively exclude Slovenian citizens from the Schengen Area. ${ }^{6}$ They responded by asserting full control over the route's path, excluding activist initiatives and only granting major NGOs, such as the Red Cross, access to people on the move, while also providing officially organized transport. Croatia, on the other hand, not yet part of the Schengen Area and with memories of refugee experience still fresh in the popular consciousness, was rhetorically more welcoming. Authorities celebrated their efficient transport of migrants across Croatia to the Slovenian border. Rhetoric aside, Croatian formalization was very similar to that of Slovenian, however. Excluded solidarity activists remarked with frustration that migrants "seem to enter a tunnel at the Serbian-Croatian border and emerge somewhere in a train station in Germany". Serbia, on the other hand, with relatively distant prospects of EU membership, pursued less formalization. As Stojić Mitrović argues, Serbian authorities saw in the route an opportunity to overcome European perception of Serbia as retrograde anti-Muslim due to its role in the wars of Yugoslav succession. They highlighted a humanitarian and welcoming approach (Stojić Mitrović 2018). When Serbian authorities did try to impose a monopoly over travel, activists in Preševo protested and publicized links between the chosen private carrier and high government officials. Their actions kept access open to a host of private and solidarity actors.

$4 \quad$ By this we refer to the rich history of anti-colonial and anti-modern struggles for self-determination that were inclusive and opened to alterity. Those struggles were most explicitly (though not without ambivalence) articulated in the national liberation struggle against Nazi and fascist occupation. Nowadays struggles against nationalist exclusivism on the territory of former Yugoslavia could be understood as an implicit or explicit continuation of such a history of struggles. We are not saying that mobility struggles are always accompanied by an anti-state ideology (though they sometimes are) but they do necessarily position migrants in conflict with state-bordering and often involve claims that other values, such as the unification with family already in Europe, trump state law. 
The formalization of the route, which enabled more than one million people to reach northern and western Europe, we argue, was an attempt to end the selfmanagement of migration and to break the co-articulation of mobility struggles and local anti-hegemonic practices, both of which have elements of escape from state-centered sovereignty and sociability. Formalization, therefore, paved the way for the repression of the opened route. Following the Paris terrorist attacks in November 2015, authorities began to filter the route; only Afghans, Iraqis, and Syrians were allowed to travel onward. Then, in March 2016, Merkel orchestrated the EU-Turkey deal to fully close the formalized corridor, pushing people back into clandestinity. When the borders closed across the region in March 2016, Croatia pivoted mercilessly - though secretly, with no public discussion - to its by now well-documented practice of illegal pushbacks, ${ }^{7}$ which regularly included detentions without any formal arrest or documentation, beatings, robberies, and involuntary and summary returns across the green border (woods and fields) into Serbia.

The case of the Hussiny family illustrates with particular brutality the reimposition of criminality on migration as well as the criminalization of solidarity, following the closure of the formalized corridor. The Croatian police apprehended this Afghan family as they rested in a park after their undocumented border crossing. The police pushed them back into Serbia along the railroad tracks. In the lights of an approaching train, they scrambled to find their four young children. They carried the bloody body of six-year-old Madina back to the Croatian authorities, who recorded her death, took her corpse, and promptly pushed the family back into Serbia. ${ }^{8}$ Still hoping to seek asylum, but understandably afraid of further pushbacks, the family contacted AYS (Are You Syrious) when they again crossed into Croatia. An activist from AYS reported their location to the nearest police station and informed the police that AYS was monitoring the case to make sure that the family got fair treatment. This activist was promptly arrested and charged with people smuggling. ${ }^{9}$ Such pushbacks of migrants, and the criminalization of solidarity, are now standard practice across much of the Balkans. Numerous migrants in Belgrade in 2017 reported to us that they had already been beaten and pushed back more than two dozen times from Croatia. In late 2017, with Serbia increasingly perceived as a dead-end, people moved in greater numbers into $\mathrm{BiH}$. With Northwest Bosnia much closer to Italy than Northwest Serbia, moving into $\mathrm{BiH}$ reduced the hostile territory people on the move had to cross from 500 to 225 kilometers. While geography was an important factor, the specificities of BiH also determined the route's evolution.

7 See https://www.borderviolence.eu/new-report-on-cases-of-torture-of-asylum-seekers-bycroatian-authorities-at-eu-external-borders/\#more-14133.

8 See https://www.theguardian.com/world/2017/dec/08/they-treated-her-like-a-dog-tragedyof-the-six-year-old-killed-at-croatian-border.

9 See https://medium.com/are-you-syrious/ays-special-when-governments-turn-against-volunteersthe-case-of-ays-81fcfe0e80e7. 


\section{BIH AND THE BALKAN ROUTE}

Multiethnic $\mathrm{BiH}$ is today a de facto international protectorate, still struggling to contain the disintegrative forces unleashed during the rise of nationalisms in the late 1980s and the ensuing 1992-1995 war. The war ended with Western military intervention and the imposition of the Dayton Agreement and Constitution that institutionalizes rule by an ethnonational logic; however, none of the three largest ethnicities enjoys a majority. Gorana Mlinarević, an independent researcher and solidarity activist, summed up the Dayton Constitution to us as fundamentally neoliberal and neocolonial, reproducing and deepening ethno-national divisions while also encouraging privatization. Asim Mujkić, a BiH political theorist, stressed that it was the reintroduction of capitalist relations of production and the concomitant imposition of the nation-form since the 1980s - something he defines as two intertwined aspects of Europeanization - that have particularly negative effects on mixed and multiethnic societies such as $\mathrm{BiH}$, leading to wars with ethnic cleansing and territorial delimitation of violently homogenized ethno-national communities. The Europeanization of $\mathrm{BiH}$, as elsewhere in ex-Yugoslavia, has been accompanied by a form of epistemic violence. This violence silences and obscures the history of autochthonous and popular alternative conceptualizations of statehood in conditions of fundamental diversity, which we discuss further below.

\section{The Evolution of the Route in $\mathrm{BiH}$}

During 2018 more than 24,000 people on the move registered their intention to seek asylum in $\mathrm{BiH}$, which temporarily legalized their stay in $\mathrm{BiH}$ (a tiny fraction of these were seeking asylum in $\mathrm{BiH}$, which is, in any case, extremely difficult to obtain). That year, more than 20,000 people managed to continue their journey clandestinely. Because of the militarization of the borders between $\mathrm{Croatia}$ and $\mathrm{BiH}$, and between Croatia and Slovenia further north, however, growing numbers find themselves stranded in $\mathrm{BiH}$. A local representative of the International Organization for Migration (IOM), Peter van der Auweraert, estimated that about 8,000 refugees and migrants were in the country in the summer of $2019 .{ }^{10}$ When the route first turned toward $\mathrm{BiH}$ in late 2017, there was distinct laxity on the part of $\mathrm{BiH}$ state authorities, and the route was primarily managed by local and international solidarity initiatives and people on the move themselves. Soon after those self-managed beginnings, a process of formalizing the route began to tame and contain mobility. On the one hand, as we learned through calls to a hotline associated with Info Kolpa (2019), the Slovenian and Croatian police further intensified and standardized violent chain pushbacks to $\mathrm{BiH}$, like earlier pushbacks to Serbia.

10 See https://www.irishtimes.com/news/world/europe/migrants-in-bosnia-face-dire-situationtrying-to-reach-eu-1.3918548. 
On the other hand, BiH authorities began to discourage the local population's material expression of solidarity with people on the move. Initially, the EU conditioned its financing of state-run reception facilities on their location far from the Croatian (i.e., the EU border). Then in November 2018, several hundred migrants and refugees blocked the $\mathrm{BiH}$-Croatian border crossing at Maljevac, demanding entry and blocking traffic for several days and sparking well-reported police repression." The EU promptly changed its policy by funding reception facilities close to the border but shifted funding away from the $\mathrm{BiH}$ state to the IOM. According to one informant in the BiH Ministry of Interior, this U-turn by the EU left the BiH authorities disoriented. At the same time, Nidžara Ahmetašević and Gorana Mlinarević, authors of a 2019 activist report on the route understood this turn as a clear symptom of BiH's neocolonial submission. In the context of the dispersed authority among the three largest ethno-national communities and degraded sovereignty of the state, intergovernmental organizations - especially the IOM - began gradually taking control over the management of the route. From early 2019, migrants and refugees are increasingly directed - when not compelled - to enter EU-funded and IOM-run reception centers in the border area (Ibid.).

With the IOM increasingly controlling housing and food for the route in $\mathrm{BiH}$, local authorities (unconstitutionally) prohibited local residents from providing services to people on the move. They established internal administrative borders to further control mobility, including checkpoints at cantonal borders, a move which had troubling echoes of wartime practices in $\mathrm{BiH}$. Following this, the reaction of the local population changes considerably. Currently, refugees and migrants encounter an ever more hostile environment, forcing them to seek basic provisions and services in overcrowded and reception camps that act as places of deterrence and discouragement. But the local response in BiH was not always hostile; initially, the local population, especially in predominantly Bosniak (Muslim) parts of the country, was very welcoming, and many locals involved themselves in solidarity activities with people on the move.

Many mosques were opened to provide shelter and assistance. This began to change when the state-sponsored Islamic Community (Islamska zajednica) officially discouraged believers from using mosques as sites of solidarity with migrants. ${ }^{12}$ This decision was surely influenced by the Bosniak political establishment's fears that Muslim solidarity would contribute to suspicions that Bosniaks in $\mathrm{BiH}$ are a breeding ground for Islamic radicalism and terrorism. As but one example of such rhetoric, a high official of the Austrian Ministry of Interior, speaking after the route had moved into $\mathrm{BiH}$, stated that the route should no longer be referred to as the Balkan Route but

11 See http://moving-europe.org/refugee-protest-camp-near-velika-kladusa-evicted/.

12 See http://www.islamskazajednica.ba/vijesti/mina-vijesti/26321-apelujemo-na-drzavneorgane-da-aktiviraju-akcione-planove-za-zbrinjavanje-izbjeglica. 
rather as the "Mosque Route"..$^{13}$ Such Islamophobic statements resonated strongly in the region, emboldening BiH Serb (Orthodox) and Croat (Catholic) nationalists, who alleged that Bosniaks were seeking to change the country's demographic balance by settling new Muslim populations. Such nationalist instrumentalization of the refugee and migrant "crisis", together with the dispersed authority and neocolonial attitude of the EU and the role of the IOM, produced a growing distance between local populations and people on the move.

These rising tensions with people on the move were tied, therefore, to the legacy of the nationalist-led war of the 1990s. After all, this was a war waged against the possibility of a mixed and multiethnic society, on existing innovative conceptions of statehood in conditions of diversity, and on Islam. As David Henig has pointed out, there have been multiple waves of ethnic cleansing on Muslim populations in the Balkans, from the wars for Greek, Bulgarian, and Serbian statehood against the Ottoman Empire through the more recent wars in BiH and Kosovo (Henig N. D.). Taken together, these expulsions resonate with the fifteenth-century Reconquista of the Iberian Peninsula by Christian forces. There is clearly a layering of contemporary European Islamophobia and the regionally-specific histories of war against Islam. The wider Western resonances of this layering were made plain by the fact that the Christchurch shooter etched the names of both medieval Serbian and more recent convicted Serbian war criminals onto the automatic weapons he used to murder 42 people in a mosque in New Zealand..$^{14}$

\section{The Foundations of Joint-Agency}

Our collaboration with local Bosniak activists made clear that forms of Islamophobia significantly inhibited the possible role of Muslim cosmopolitanism as a foundation of joint-agency. When we asked one solidarity activist, who described herself as a pious Muslim, about the reason for the Islamic Community's intervention against solidarity, she said that it probably happened because Bosniak solidarity with people on the move could be misunderstood. One Bosniak researcher of migration even suggested to us that the best solution for $\mathrm{BiH}$ would be if the EU established hot spots on $\mathrm{BiH}$ territory. This practice, he surmised, would take the process wholly out of $\mathrm{BiH}$ hands, avoiding any reason to suspect the intentions of $\mathrm{BiH}$ authorities - especially Bosniaks - in dealing with refugees and migrants from predominantly Muslim countries. Additionally, Asim Mujkić described to us the negative reactions of Bosniaks to the presence of migrants and refugees, as the "otherwise orientalized orientalizing others". The internalization of Islamophobia, in other words, was instrumental in inhibiting Muslim cosmopolitanism as a foundation of joint-agency.

13 See Radio Slobodna Evropa "Austrijski ministar: Nova 'džamijska ruta' za migrante ka EU", https://www.slobodnaevropa.org/a/29265324.html, 2018.

14 See https://www.aljazeera.com/news/2019/03/zealand-mosque-gunman-inspired-serbnationalism-190315141305756.html. 
Although the Bosniak community in BiH still harbors antinationalist sentiments and conceptions of $\mathrm{BiH}$ as inclusive mixed and multiethnic, the processes of nationalizing and racializing of the Bosniak community and BiH Islam increasingly mark the Bosniak political landscape (Šačić 2007). Religious Bosniaks, often openly expressed blatantly racist views regarding refugees and migrants. Many expressed the civilizational superiority of BiH Islam and explicitly laid claim to its European character. One imam near the $\mathrm{BiH}$-Croatian border, who expressed sympathy with those traveling and recounted his own material support for people, nonetheless stressed that these were not Europeans like "we Bosniaks" and needed to be civilized. "They cannot be assimilated," another asserted. Of course, as Catherine Baker's Race and the Yugoslav Region (2018) makes clear, there are also deeply seated racializing dynamics in the wider region. Still, European Islamophobia has, nonetheless, structured the distinct ways race has come to be articulated in $\mathrm{BiH}$.

Our engagement with local solidarity activism in BiH suggests that local people supporting people on the move - not unlike those in Preševo, Eastern Slavonia, and Serbia - frequently refer to their own refuge experience during the 1990s. Local opposition to the formalization of the route, i.e., to the channeling of migrants and refugees into IOM-managed reception camps, was also articulated upon past refuge experience in the border town of Velika Kladuša. One local volunteer involved in this emergent initiative, an elementary school teacher who described herself as a devout Muslim with strong cultural ties to Turkey, discussed her experience of fleeing "illegally" to Germany during the war. This shared condition of refuge is, therefore, another foundation of joint-agency, especially if we understand refuge-ism in the 1990 s as the direct result of the nationalist war against mixed and multiethnic $\mathrm{BiH}$ society. The other typical local narration of solidarity with migrants was from volunteers who had been politicized during the dramatic wave of popular uprisings that spread across BiH in February 2014 or in the massive local solidarity response to a wave of disastrous floods in May 2014. In particular, the uprisings were the first significant expression of antinationalist and transethnic political articulation in $\mathrm{BiH}$ since the war, with protesters stressing the shared suffering of ordinary citizens at the hands of a corrupt and greedy political class who instrumentalized ethnicity for their own narrow ends (Kurtović 2015; Mujkić 2015).

What is common to both references - the past experience of refuge and newer types of social activism - is their critical relation to the violent imposition of the (European) nation-form onto the complex ethnonational composition of $\mathrm{BiH}$, attributable to its Ottoman and Hapsburg imperial legacies. The competing but isomorphic nationalist political projects caused the war and left a legacy of (partial) territorial separation in $\mathrm{BiH}$ along ethnic lines making, what Jasmin Hasanović has characterized as, a "post-conflict state of the colonial imagination designed upon the results of war" (Hasanović 2016). In the same way, a new generation of social activism in $\mathrm{BiH}$ has been distinguished by its refusal of ethnonational divisions and its consistent articulation of the solidarity that transcends them. As we have argued, 
these anti-hegemonic social practices resonate deeply with previous popular antinationalist conceptualizations that informed the specific history of the anti-fascist liberation struggle during WWII, with national liberation councils organized along inclusive multiethnic and grassroots forms of self-government. These forms, in turn, significantly influenced the Yugoslav model of socialism after WWII, including its distinctive model of worker self-management.

What is more, the experience of the anti-fascist liberation struggle and the experience of subjugation in the Ottoman and Austro-Hungarian Empires until the twentieth century, undoubtedly contributed to the anti-colonial sensibilities that led Yugoslavia to be the only European state to participate in the founding of the Non-Aligned Movement. This anti-colonial experience continued to resonate with the route, not only in the experiences like those of the imam in Preševo but with others we met along the route, such as several volunteer translators who were the children of Arabs who settled in Yugoslavia after studying there through Non-Aligned Movement exchanges. Such connections are affirmed by political theorists like Asim Mujkić, whose conceptualization of a "Bosnian paradigm" is inspired by reflections on new social movements in $\mathrm{BiH}$ that intersect with struggles for freedom of movement. The Bosnian paradigm highlights traditions and ongoing practices that consistently subvert attempts to impose the nation-form characteristic of European modernity. Mujkić theorizes Bosnia as "corpus separatum", that is, a "body that is not uniform and homogeneous, but made instead of differences in a constant process of differentiation, which might look to integralist eyes like confusing dis-integration, while it is, actually, a qualitatively new aspect of integration" (2019: 10).

\section{CONCLUSION}

In narrating the opening of the Balkan Route across the territory of ex-Yugoslavia, we build on the critical tradition of the autonomy of migration, emphasizing the central role of people on the move. Positioning our militant research at the interface between the autonomy of migration and its interactions with local support across ex-Yugoslavia, we found ourselves compelled to attend as well to what we call joint-agency. Joint-agency has implications on the conceptualization of the role of the mobile commons, those self-organized forms of migration infrastructure and knowledge production (Papadopoulus, Tsianos 2013)..$^{15}$ The self-managed infrastructure of mobility we highlight emerges from both practices of mobility and their interactions with local solidarity practices and less tangible local social traditions that condition mobility. But forms of autonomy are, of course, always relational, and they create fields of mutually transformative engagements.

15 We would note that the mobile commons also includes creative reappropriations of institutionalized forms making it sometimes difficult to discern when those forms alternately allow and impede mobility. 
We refute claims that the extraordinary opening of the borders of EUrope was the result of humanitarian gestures by states rather than of people's mobility struggles. Humanitarian discourses and practices, not least the establishment of the formalized corridor in September of 2015, nonetheless served to eventually reassert control over mobility through the externalization of EUropean border and migration regimes into the borderlands of ex-Yugoslavia. From the perspective of joint-agency, we have therefore recast the history of the formalization and eventual closing of the route through ex-Yugoslavia and its current post-corridor BiH predicament. Whereas Europeanization is so often represented as the cure for all that ails the Balkans, here the process assumes an appropriately dubious and troubling association. The EUropeanization of the migrant route, i.e., the imposition of EU control over mobility, resonates with other layers and meanings of Europeanization and alerts us to its persistent colonial character.

For example, the formalization of the route, which was a precondition of subsequent control over unruly mobility, was significantly determined by forms of othering that are embedded within the deeply entrenched colonial prejudice that people in this European borderland are themselves incapable of self-rule. Such prejudice is especially forceful in $\mathrm{BiH}$, in which the processes of formalization of the route circumvented state and local authorities and introduced international organizations of mobility control, such as the IOM, which acts as a de facto parallel government. Another meaning and layer of Europeanization that structures the formalization of the migrant route and reestablishment of mobility control - by far the most destructive for ex-Yugoslavia in general and $\mathrm{BiH}$ in particular - is the imposition of the nation-form on this ethnically and religiously heterogeneous territory. Its recent reintroduction at the beginning of the 1990s displaced inclusive forms of selfgovernment developed in relation to this heterogeneous society, instead imposing exclusive and subordinate forms of government that are hostile to alterity. The subordination of ex-Yugoslav states through their hierarchical integration into the EU (Razsa, Kurnik 2014) has certainly been instrumental in restoring the EU border and migration regime.

We are writing this conclusion as the (intentionally) poor management ${ }^{16}$ of the "migrant crisis" in BiH is producing increasingly hostile local reactions, including the racializing violence of local police in BiH's Una Sana Canton (which includes Bihać and Velika Kladuša). Those incidents decisively reintroduce questions of race in a locality that, due to its nominal exteriority to the colonial history of the Western imperial powers, was supposedly exempt from colonial racialization (Todorova 2009), confirming our previous observations regarding the role of racism when we discussed formalization as an attack on joint-agency. Racialization does have a significant role in EUropean mobility control as reintroduced on the territory of ex-Yugoslavia, both

16 This claim is based on our observations from the field and additionally supported by the conclusion of the report on people on the move in BiH by Ahmetašević and Mlinarević (2019). 
as the result of the introduction of nation-form with concomitant internal colonization (Bjelić 2018) or as a product of Islamophobia, which is foundational for European identity. According to Trouillot, the foundational event of 1492 was the Reconquista and expulsion of Muslims (and Jews). Europe, he argues, constituted itself as foundationally Christian on the eve of the modern colonial enterprise (Trouillot 2003). The continuing echoes of this self-definition of Europe significantly affect the response of $\mathrm{BiH}$ public authorities to the presence of people on the move. At the same time, the nationalization of $\mathrm{BiH}$ Islam reinforces racialization and erodes possibilities of Muslim cosmopolitism as one (of many) foundations for joint-agency along the route.

The extension of the EUropean border and migration regime on the territory of former Yugoslavia points to and depends upon various dimensions of Europeanization. The instability of this process, on the other hand, reveals the capacity of people on the move to reappropriate conditions of mobility that intersect with silenced local legacies of various struggles against political projects of hegemony based on modern European notions of sovereignty and nationality. The history of the Balkan Route and its current predicament in $\mathrm{BiH}$, therefore, cannot be understood without considering the joint-agency we described across various localities along the Balkan Route across the ex-Yugoslav territory. Furthermore, attention to joint-agency, to these ad hoc collaborations, can offer an opportunity to amplify emergent forms of postcolonial critique that draw upon local anti-hegemonic traditions in various localities around migrant routes (i.e., not only in the Balkans). In this way, migration as a practice of critique of coloniality also contributes to forms of epistemological self-determination and - potentially - to the political self-determination of localities around a variety of migrant routes.

\section{REFERENCES}

Ahmetašević, Nidžara, Mlinarević, Gorana (2019). People on the Move in Bosnia and Herzegovina in 2018: Stuck in the Corridors to the EU. Sarajevo: Heinrich Böll Stiftung $\mathrm{BiH} /$ North Macedonia/Albania.

Balibar, Étienne (2004). We the People of Europe? Reflections on Transnational Citizenship. Princeton: Princeton University Press.

Beznec, Barbara (2019). Solidarity Route. Ljubljana: Manuscript.

Beznec, Barbara, Speer, Marc, Stojić Mitrović, Marta (2016). Governing the Balkan Route: Macedonia, Serbia and the European Border Regime. Beograd: 5. Research Paper Series of Rosa Luxemburg Stiftung Southeast Europe.

Bjelić, Dušan I. (2018). Toward a Genealogy of the Balkan Discourses on Race. Interventions 20/6, 906-929, https://doi.org/10.1080/1369801X.2018.1492955.

Casas Cortes, Maribel, Cobarrubias, Sebastian, Pickles, John (2015). Riding Routes and Itinerant Borders: Autonomy of Migration and Border Externalization. Antipode 47/4, 894-914, https://doi.org/10.1111/anti.12148. 
De Genova, Nicholas (2017). Introduction. The Borders of 'Europe' and the European Question. The Borders of 'Europe' (ed. Nicholas De Genova). Durham, NC: Duke University Press, 1-35.

El-Shaarawi, Nadia, Razsa, Maple (2019). Movements upon Movements: Refugee and Activist Struggles to Open the Balkan Route to Europe. History and Anthropology 30/1, 91-112, https://doi.org/10.1080/02757206.2018.1530668.

Hasanović, Jasmin (2016). Geopolitički kontekst postdejtonske igre suvereniteta: Između suverene i postsuverene Bosne i Hercegovine. Pregled 57/1, 163-182.

Henig, David (N. D.). Manuscript.

Info Kolpa (2019). Poročilo o nezakonitih izgonih na slovensko-hrvaški meji, http://www. pushforward.org (7. 7. 2019).

Hameršak, Marijana, Pleše, Iva (2017). Zarobljeni u kretanju: O hrvatskoj dionici balkanskog koridora. Kamp, koridor, granica (eds. Emina Bužinkić, Marijana Hameršak). Zagreb: Institut za etnologiju i folkloristiku, 9-39.

Kasparek, Bernd, Speer, Max (2019). Of Hope: Hungary and the long summer of migration, https://bordermonitoring.eu/ungarn/2015/09/of-hope-en/ (7. 7. 2019).

Kurnik, Andrej (2015). Hvala, ker odpirate Evropo. Casopis za kritiko znanosti 262, 225-240. Kurtović, Larisa (2015). "Who Sows Hunger, Reaps Rage": On Protest, Indignation and Redistributive Justice in Post-Dayton Bosnia-Herzegovina. Southeast European and Black Sea Studies 15/4, 639-659, https://doi.org/10.1080/14683857.2015.1126095.

Lunaček Brumen, Sarah, Meh, Ela (2016). "Vzpon in padec" koridorja: Nekaj refleksij o spremembah na balkanski migracijski poti od poletja 2015. Časopis za kritiko znanosti 264, 21-45.

Mujkić, Asim (2015). In Search of a Democratic Counter-Power in Bosnia-Herzegovina. Southeast European and Black Sea Studies 15/4, 623-638, https://doi.org/10.10 80/14683857.2015.1126094.

Mujkić, Asim (2019). Bosanska paradigma i njezina dezintegracija. Sarajevo: Manuscript. Papadopoulus, Dimitris, Stephenson, Niamh, Tsianos, Vassilis (2008). Escape Routes: Control and Subversion in the Twenty-first Century. London: Pluto Press.

Papadopoulus, Dimitris, Tsianos, Vassilis (2013). After Citizenship: Autonomy of Migration, Organisational Ontology and Mobile Commons. Citizens Studies 17/2, 178-196, https://doi.org/10.1080/13621025.2013.780736.

Razsa, Maple, Kurnik, Andrej (2012). The Occupy Movement in Žižek's Hometown: Direct Democracy and a Politics of Becoming. American Ethnologist 39/2, 238-258, https://doi.org/10.1111/j.1548-1425.2012.01361.x.

Razsa, Maple, Kurnik, Andrej (2014). Occupy Slovenia: How Migrant Workers Contributed to New Forms of Direct Democracy. Border Politics: Social Movements, Collective Identities, and Globalization (eds. Nancy A. Naples, Jennifer Bickham Mendez). New York, London: New York University Press, 206-229.

Stojić Mitrović, Marta (2018). The Reception of Migrants in Serbia: Policies, Practices, and Concepts. Journal of Human Rights and Social Work 4/1, 1-11, https://doi. org/10.1007/s41134-018-0077-0. 
Šačić, Nermina (2007). Izvan politike. Sarajevo: Fakultet političkih nauka.

Tazzioli, Martina (2017). The Government of Migrant Mobs: Temporary Divisible Multiplicities in Border Zones. European Journal of Social Theory 20/4, 473-490, https://doi.org/10.1177/1368431016658894.

Todorova, Maria (2009). Imagining the Balkans. Oxford: Oxford University Press.

Trouillot, Michel Rolph (2003). Global Transformations: Anthropology and the Modern World. New York: Palgrave Macmillan. 


\section{POVZETEK}

\section{REAPROPRIACIJA BALKANSKE POTI: BOJI ZA MOBILNOST IN SO-DELUJOČNOST V BOSNI IN HERCEGOVNI Andrej KURNIK, Maple RAZSA}

Pri pisanju zgodovine odpiranja in zapiranja Balkanske poti je treba upoštevati določujočo vlogo bojev za svobodo gibanja. Ti boji niso izolirani od lokalnega okolja, v katerem se odvijajo, ampak tvorijo svojevrstno ekologijo mobilnosti. Pojem so-delujočnost, s katerim avtorja označujeta vzajemno artikulacijo bojev za mobilnost in lokalnih protihegemonskih tradicij in diskurzov, ponuja specifično perspektivo za pisanje zgodovine begunskih in migrantskih poti, kakršna je Balkanska.

S tega stališča odprtja begunskega koridorja leta 2015 ne moremo razumeti kot humanitarno gesto, ampak kot koncesijo, ki so jo oblastem vsilili boji za svobodo gibanja. Aktivistično raziskovanje nekaterih mejnih lokacij na območju nekdanje Jugoslavije, ki so bile ključne za odprtje begunske poti, je pokazalo, da so boji za svobodo gibanja tvorili so-delujočnost z lokalnimi praksami in s tradicijami nasprotovanja hegemonskim političnim projektom, ki slonijo na državni suverenosti in nacionalni formi. Za restavracijo evropskega migracijskega in mejnega režima, ki ga je v času zapiranja koridorja pomembno določala hierarhična vključenost posameznih držav v evropske integracije, je značilno razbijanje te so-delujočnosti na način vzpostavljanja monopola oblasti nad begunsko in migrantsko potjo.

Formalizacija migrantske poti na način spodkopavanja so-delujočnosti v Bosni in Hercegovini izhaja iz kolonialnega predsodka, da so drugi nezmožni samovladanja, islamofobije, vsiljevanja nacionalne forme in rasizma. Nestabilnost restavracije evropskega migracijskega in mejnega režima v BIH pa kaže tudi na vztrajnost avtentičnih ljudskih konceptualizacij skupnega življenja v razmerah različnosti in heterogenosti. Migracija ter begunske in migrantske poti imajo potemtakem potencial, da oživijo lokalne kritike kolonialnosti oblasti in evropeizacije, ki vsiljuje moderne in na nacionalno državo usmerjene konceptualizacije skupnega življenja. 